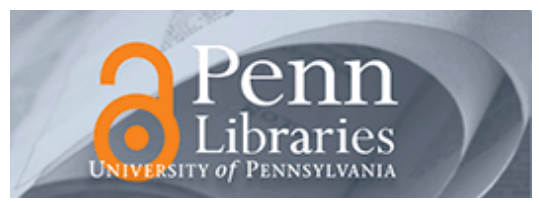

University of Pennsylvania ScholarlyCommons

November 2008

\title{
Hurricane Katrina and New Orleans: What Might a Sociological Embeddedness Perspective Offer Disaster Research and Planning?
}

Roberta R. Iversen

University of Pennsylvania, riversen@sp2.upenn.edu

Annie Laurie Armstrong

Business Government Community Connections

Follow this and additional works at: https://repository.upenn.edu/spp_papers

\section{Recommended Citation}

Iversen, R. R., \& Armstrong, A. (2008). Hurricane Katrina and New Orleans: What Might a Sociological Embeddedness Perspective Offer Disaster Research and Planning?. Retrieved from

https://repository.upenn.edu/spp_papers/137

Pre-peer reviewed version. Published in Analyses of Social Issues and Public Policy, Volume 8, Issue 1, November 2008, pp. 183-209.

The definitive version is available at http://dx.doi.org/10.1111/j.1530-2415.2008.00164.x

This paper is posted at ScholarlyCommons. https://repository.upenn.edu/spp_papers/137

For more information, please contact repository@pobox.upenn.edu. 


\title{
Hurricane Katrina and New Orleans: What Might a Sociological Embeddedness Perspective Offer Disaster Research and Planning?
}

\author{
Abstract \\ The Hurricane Katrina and NewOrleans situation was commonly called a "natural disaster" - an \\ anomalous "event" that disrupted lives, spaces, and organizations. Research and planning attention then \\ focused on particular aspects of the event and on restoring order. In contrast, sociologists and similar- \\ thinking scholars have increasingly viewed disaster situations from multiple locations and histories, often \\ using systems theory. Here, reanalysis of empirical material from ethnographic research in New Orleans \\ pre- and post-Katrina suggests that a sociological embeddedness perspective illustrates the dynamic \\ seamlessness of past, present, and future economic contexts and social actions. The perspective's \\ constitutive concepts of weak, strong, and differentiated ties highlight the role of local knowledge, \\ intermediary-led workforce networks, and sustained participatory planning in creating a robust economic \\ environment. Toward this end, disaster research, planning, and theory building could incorporate network \\ tie assessments into social vulnerability protocols, compare embeddedness with other perspectives, and \\ learn from related international experiences.
}

\section{Comments}

Pre-peer reviewed version. Published in Analyses of Social Issues and Public Policy, Volume 8, Issue 1, November 2008, pp. 183-209.

The definitive version is available at http://dx.doi.org/10.1111/j.1530-2415.2008.00164.x 
Hurricane Katrina and New Orleans: What Might a Sociological Embeddedness Perspective Offer Disaster Research and Planning?

Roberta Rehner Iversen*

University of Pennsylvania

Annie Laurie Armstrong

Business Government Community Connections, Seattle, Washington

The Hurricane Katrina and New Orleans situation was commonly called a "natural disaster" —an anomalous “event” that disrupted lives, spaces, and organizations. Research and planning attention then focused on particular aspects of the event and on restoring order. In contrast, sociologists and similar-thinking scholars have increasingly viewed disaster situations from multiple locations and histories, often using systems theory. Here, reanalysis of empirical material from ethnographic research in New Orleans pre-and post-Katrina suggests that a sociological embeddedness perspective illustrates the dynamic seamlessness of past, present, and future economic contexts and social actions. The perspective's constitutive concepts of weak, strong, and differentiated ties highlight the role of local knowledge, intermediary-led workforce networks, and sustained participatory planning in creating a robust economic environment. Toward this end, disaster research, planning, and theory building could incorporate network tie assessments into social vulnerability protocols, compare embeddedness with other perspectives, and learn from related international experiences.

Scholars from numerous disciplines have contributed notably to knowledge about disaster prevention, response, and recovery, yet they and most of the general public viewed Hurricane Katrina and New Orleans in August 2005 as a "natural disaster"—an anomalous "event" that 
disrupted lives, spaces, organizations, and institutions. By implication, these lives, spaces, organizations, and institutions were functioning adequately before the act of nature, thus the disruption only required interventions that would facilitate recovery or reestablishment of the prior state. In contrast, over the last couple of decades, disaster sociologists, as well as scholars from psychology, political science, anthropology, geography, and disaster research centers, came to see disasters as multifaceted, which led them to view the Hurricane Katrina-New Orleans situation as a mix of "natural" and "human-made" or "technological” causes and as a historically conditioned process (Brunsma, Overfelt, \& Picou, 2007; Colten, 2006; Hartman \& Squires, 2006; Oliver-Smith, 1996, 2006; Perry, 2005; Perry \& Quarantelli, 2005). As such, these more complex theoretical perspectives on disaster were often based on systems theory (Barber, 1995; Erikson, 2007; Ibata-Arens, Dierkes, \& Zorn, 2006), which commonly posited discrete human and institutional actors, the goal of equilibrium or reestablishment of the status quo, binary distinctions between micro and macro or humans and nature, and at one extreme, a view in which "problems" are "attacked" through "social engineering" and the mentality of "expertism” (Montuori \& Purser, 1996, p. 185). From a traditional systems perspective, little attention was paid to local knowledge and participatory planning.

An additional limitation of viewing the Hurricane KatrinaNew Orleans situation exclusively from traditional systems theory is that, epistemologically and practically, it maintains the fiction that "events" and social actors are at the same time bound together and yet independent of each other - a view that is paralleled by the structure of autonomous government departments and funding streams that provide institutionally separate prevention, response, or recovery efforts. For example, the Federal Emergency Management Agency (FEMA) addresses temporary housing concerns in New Orleans and the U.S. Department 
of Housing and Urban Development (HUD) addresses longer-term concerns, but neither concern has been addressed effectively (Cooper \& Block, 2006), even 3 years after Katrina. Similarly, other components of an economic infrastructure, such as transportation, education and job training, child care, and employment, functioned autonomously in relation to the work efforts of many New Orleans residents before Katrina, and although these vitally related areas are essential to rebuilding the city economy, they remain structured and perceived as separate spheres. Arguably, contemporary system-based scholarship could yield more-valuable knowledge about the Hurricane Katrina-New Orleans situation, as it has emphasized the notions of dynamic processes and webs of connected relationships between the system parts that could even be considered mutually constitutive (Montuori \& Purser, 1996). Nevertheless, most disaster scholarship is based on the more constricted and totalizing nature of earlier systems concepts.

In this context, as we reanalyzed empirical material on lowincome families and economic mobility from longitudinal ethnographic research we conducted in New Orleans before and after Hurricane Katrina, the underlying systems perspective that guided the original study (Iversen \& Armstrong, 2006) did not seem to fully explain the embeddedness of New Orleans's economic situation after the storm and levee failures in the city's economic infrastructure over prior decades. Indeed, the possibility that a sociological embeddedness perspective might provide a particularly inclusive understanding of this disaster situation emerged inductively from these analyses, which we explore more fully in this article. As such, this article adds a new dimension to the earlier ethnographic findings and, in line with both Tierney's (2007) and Quarantelli's (2005) plea for further theoretical development in disaster research, hopes to open new theoretical territory for disaster sociologists and other 
disaster scholars who find the new landscape compelling. This theoretical direction also holds the promise/potential of more adequate, relevant, and just problem viewpoints and planning directions.

Briefly, an embeddedness perspective, with its theoretical origins in economic sociology (Granovetter, 1985, 1992b, 2005; Polanyi, 2001/1944), posited economic action as social action (Jagd, 2007). It explicitly contested the neoclassical economics perspective which held that economic action was motivated by individualistic selfinterest and utility maximization, and thus left little room for solidarity, joint decision-making, or altruistic motivation for action. In other words, from an embeddedness perspective, economic, political, and relational phenomena are constitutive of social/economic action via networks of interpersonal and interorganizational "ties," which are, to greater or lesser extents, formed out of trusted, reciprocal, and sustained relationships. Although anthropological scholars have also valuably put forth a perspective on embeddedness (Moody \& White, 2003; Oliver-Smith, 2006; Schweizer, 1997), the sociological version is primary in this article for three reasons: it emphasizes the importance of network ties, which emerged as important in our research; the anthropological version tends to retain a systems orientation, even as it speaks of embeddedness; and anthropologists have taken the concept outside of the Granovetterian emphasis on economic action, which is this article's focus. Accordingly, an embeddedness perspective in this article refers to the sociological version, which is amplified further in a later section.

Specifically, we explore embedded networks in this article via their constitutive presence in the everyday phenomena of education and job training, labor market opportunity, and work policy supports, such as affordable child care and adequate transportation, and particularly via a new form of community organization known as workforce 
intermediaries (Giloth, 2004), which by their very structure and purpose, foster ties among human and organizational actors in urban locales such as New Orleans. This exploration seems increasingly necessary because disasters, as sociologically conceptualized, are on the rise in the United States and elsewhere due to increased development of physically hazardous parts of coastal or river-bank cities (Achenbach, 2008), the parallel increase in population density in disaster-prone areas (Picou \& Marshall, 2007, p. 5), and politically influenced decisions about building shortcuts in those areas (Johnson, 2008). For example, Revkin (2008) characterized the outcome of the 2008 cyclone in Myanmar in terms similar to those used for decades about New Orleans: "Deltas are disaster zones in waiting” (p. 3). In the United States, according to Dynes and Rodriguez (2007), “coastal counties constitute about $17 \%$ of the landmass (excluding Alaska), but $53 \%$ of the U.S. population (153 million people) live in these areas” (p. 31). Moreover, unequally distributed risks and results of disaster situations by economic status have been well documented, both in the United States and internationally, as Maruyama and Ruscher's (2006) special issue on Hurricane Katrina and New Orleans in Analysis of Social issues and Public Policy richly illustrated. Referring to Katrina and the South Asian tsunami as exemplars, Beck (2006) contended that, locally and globally, "catastrophic risk follows the poor" (p. 339), a contention that Erikson (2006) expanded upon: "acute disasters very often visit the homes of people who have already been the victim of chronic disasters" (p. 11). Although wealthier families in New Orleans were also dislocated and deprived of homes and jobs, greater resources resulted in greater protection and resilience for most of them (Colten, 2006; Logan, 2006).

Thus, because a systems perspective on disaster situations tends toward atomism rather than pluralism, and because disaster situations seem to be increasingly prevalent, this 
article explores how a sociological embeddedness perspective might enhance participatory disaster prevention and mitigation and lead to more inclusive disaster and infrastructure planning, as follows. First, theoretical perspectives on disaster from multiple disciplines and from sociology are examined for their difference from, but possible movement toward, an embeddedness perspective. The concept of embeddedness is then presented more fully, particularly in relation to network ties, and a short section on the empirical and spatial context of the ethnographic research follows. The next section describes how the lived experiences of the New Orleans research families illustrate embeddedness and network ties; in particular, how well-or insufficiently embedded networks forward or constrain the families' economic progress, dynamically and over time. The concluding section addresses theoretical and practical implications of broader incorporation of a social embeddedness perspective, both nationally and internationally.

\section{Theoretical Perspectives on Disaster}

\section{Perspectives from Multiple Disciplines}

Disaster scholarship's focus on a particular part of a disruptive "event" generally directed research and policy to a single aspect of the phenomenon, such as persons, institutions or the built environment. For example, although greatly simplified here, disaster scholars from the fields of psychology and social psychology frequently addressed human behavior and individual well-being (Gist, Lubin, \& Red-burn, 1998; see also the first Special Issue on Katrina, Analysis of Social Issues and Public Policy, 6(1), 2006). Relevant to the Hurricane Katrina-New Orleans situation, these scholars valuably explored developmental factors and interventions that compounded or mediated stress (Gist et al., 1998). They also highlighted emergent community or neighborhood helping networks (Rodr' 1 guez, Trainor, \& 
Quarantelli, 2006) or identified "system justification processes” (Napier, Mandizodza, Anderson, \& Jost, 2006), such as stereotyping and victim-blaming. Others, from disciplines that include political science and social psychology, extensively documented the disproportionate suffering and disadvantage in post-Katrina New Orleans by characteristics such as race, gender, class, and age (Enarson, 2006; Gilman, 2006; Logan, 2006).

Another set of scholars, perhaps the largest although not discipline specific, focused a technological, techno-political or techno-health lens on creating and implementing institutional or organizational strategies for disaster preparation and recovery management (Alexander, 2006; Donohue, Masilela, \& Gear, 2000; Friedman \& Relave, 2005; Kettl, 2006), including the modeling of causal chains (Venton \& Hansford, 2006). This research centered on managerial practices and operational capacities at city, state, and federal levels of government. In New Orleans, this meant identifying what prevention plans had been in place, what communications, resources, and supplies were needed immediately after the hurricane, and later, in microscopic detail, analysis of what went wrong where, when and why. Still others, often from the fields of geography or engineering, directed a spatial, geophysical lens on nature and natural forces (Gordon, 2007; United States Risk Management, 2007). Such lenses focused on the built environment and land use, primarily to assess reconstruction strategies, although some assessed the interface of the geophysical and social as well (Cutter \& Emrich, 2006). In New Orleans, this meant analyzing ways to strengthen the levee system and assessing which spaces were and were not physically sound for rebuilding.

The predominant emphasis on response and recovery, and on conceptualizing the Hurricane Katrina-New Orleans situation as a "natural disaster" and as an "event" in much of this literature underscored Quarantelli’s (2005) 
contention that disaster research has been approached ahistorically since the beginning of the field. In contrast, sociological lenses on disaster have increasingly been multifocal and multivariate (Perry, 2005; Perry \& Quarantelli, 2005).

\section{Sociological and Related Perspectives on Disaster}

Generally speaking, a sociological orientation to disaster theory and research has emphasized the intersections and interactions between personal lives and the socio-politicaleconomic environment in which lives were lived. In other words, the field of disaster sociology applied theoretical understanding about society to social phenomena and to research-based social policies and practices in turn, as two extremely reflective overviews of the field have shown (Quarantelli, 2005; Tierney, 2007). As such, most disaster sociologists, as well as sociologically oriented disaster scholars from other disciplines, viewed a situation such as Hurricane Katrina and New Orleans from multiple locations and histories - often from a systems perspective, as discussed earlier, or from a social vulnerability approach or mix of the two (Cutter, Boruff, \& Shirley, 2003; Cutter 2005, 2006; Cutter \& Emrich, 2006; Tierney, 2006, 2007; Tierney, Bevc, \& Kuligowski, 2006; Wisner, 2001). The social construction of the situation, historical lodging, and emphasis on social structure were features of these approaches that moved toward an embeddedness perspective, although more implicitly than explicitly.

For example, toward the notion of constructed rather than factual truths, Hartmann (1999) argued that, “Actors' interpretation of disasters crucially depends on the political and social environment in which they occur" (p. 1, emphasis added). Similarly, Stahl, Lichtenstein, and Mangan (2003) characterized responses to a situation such as a hurricane as "depending on social agreements and individual perceptions” (p. 18); in effect, as Quarantelli 
(2005) contended, as a constructed "social problem" rather than as a "focused occasion in terms of time and space" (p. 334). Notably, Granovetter (1992a) himself associated constructionism with embeddedness, contending that, "economic institutions do not emerge automatically in response to economic needs; rather, they are constructed by individuals whose action is both facilitated and constrained by the structure and resources available in social networks in which they are embedded" (p. 7). Given the importance of language to constructionism, Stallings (2005) characterized what others call a "disaster," a "social situation," which this article has amended to "disaster situation."

Regarding historical lodging, a collection of multidisciplinary scholars' responses to Hurricane Katrina in a recent volume edited by Hartman and Squires (2006) fully acknowledged the role of the past in creating the conditions for disaster in New Orleans, via both systems and social vulnerability perspectives. These contributions implied, but did not explicitly identify that poor health, housing, environmental, education, labor market, and employment conditions were embedded in the economic and social action of human and institutional actors in preKatrina New Orleans.

Similarly, a volume of recent sociological contributions, edited by Brunsma, Overfelt, and Picou (2007), actively redressed Quarantelli's (2005) concern about the ahistorical nature of disaster research. However, as Tierney (2007) contended elsewhere about the field in general, Clarke (2007) charged that current disaster literature, including the Brunsma et al. volume, has concentrated mostly on what happened during and immediately after Katrina, rather than on what happened before the storm and what will happen in the future (p. 237). As such, he concluded that, "we need a lot more attention on what creates the conditions that lead to calamity in the first place” (p. 237). Along these lines, 
while the contributions in the Brunsma et al. volume did not explicitly conceptualize disaster situations as embedded, Barnshaw and Trainor's (2007) chapter focused on "the process of social capital conversion/ transformation into resources [during disasters]" (p. 95) ...which "highlights the form and operation of the networks within which resources are embedded" (p. 96). As such, Barnshaw and Trainor moved firmly toward the embeddedness perspective discussed in this article, even though their chapter still evidenced a lingering systems orientation whereby individuals, social structures, and social institutions were located on intersecting rather than mutually constitutive paths.

Along structural lines, Quarantelli (2005) contended that "disasters are inherently social phenomena and that the source of disasters is rooted in the social structure or social system” (p. 339). Extending Quarantelli's view, Hilhorst's (2003) "mutuality paradigm" looked at the mutual constitution of society and environment (p. 2). Other sociologists took a structural social vulnerability approach to disaster research, emphasizing, as have some anthropologists and geographers, "the social creation of vulnerability” (Oliver-Smith, 1996, p. 314). Kroll-Smith (2001) argued for a "vulnerability analysis,” which by definition implied different levels of risk (Smith, 2006), holding that, "disasters are always more than physical catastrophes with social consequences; they are also the outcome of a complex and long-running interplay of power and geography that works to shield some people from the whims of nature or the negligence of dangerous industries while exposing others to the unwanted fallout of these acts of nature and man" (Kroll-Smith, p. 175). Similarly, Erikson (2006) contended that while we have become more adept at technological measurement of hurricanes, we are not good at "calculating the levels of the vulnerability of the human, social and environmental landscapes that disasters strike” (p. 7). He called for the development of a 
vulnerability index, which, by then, had been created by sociologically oriented cultural geographers (Cutter, 2005; Cutter, Boruff, \& Shirley, 2003) and called the Social Vulnerability Index (SoVI). When Cutter and colleagues (2003) developed the SoVI, they worked from the partsystems, part-embeddedness premise that "social vulnerability is partially the product of social inequalities .... however, it also includes place inequalities - those characteristics of communities and the built environment, such as the level of urbanization, growth rates, and economic vitality, that contribute to [i.e. constitute] the social vulnerability of places” (p. 243). In a sense, the index's continuous and dynamic association of an area's social, political and economic hazards with the area's vulnerability to a disaster situation implied the notion of embeddedness and its constitutive structural influences.

Similarly, Tierney's (2007) emphasis on the inherent lodging of disaster situations in community life, and on the "need for strengthening community resilience, building public-private partnerships, reaching out to marginalized community residents and their trusted institutions, and developing consensus-based coordinating mechanisms at the interorganizational, community, and intergovernmental levels” (Tierney et al., 2006, p. 76), approached the idea of embeddedness in its focus on the need for participatory, multimodal, and networked planning. Finally, anthropologists Breunlin and Regis (2006) made brief mention of embeddedness and network ties in their analysis of the Hurricane Katrina-New Orleans situation, demonstrating that both concepts are well-suited for multidisciplinary examination.

In sum, these sociological and related disciplinary positions on disaster situations not only valuably posited a systemic interrelatedness of persons, organizations and institutions, but some also moved toward the notion that economic and 
social actions are embedded in-that is, are constitutive of - an urban environment's structures, policies and practices. This embeddedness perspective is amplified next.

\section{Embeddedness and Network Ties}

Although Polanyi (2001/1944) and Weber (1978/1922), respectively, mentioned or implied the concept of embeddedness, Granovetter (1985) produced the seminal formulation of the concept, which he initially described as, "the extent to which economic action [behavior] is embedded in structures of social relations” (p. 481), and later (1992a) as, "the embeddedness of economic goals and activities in socially oriented goals and structures" (p. 3). Most recently, Granovetter described embeddedness as, "the way social and economic activities are mixed up with networks of social relations” (Krippner, Granovetter, Block, Biggart, \& Beamish, 2004, p. 113). Swedberg (2003) contended similarly that "an economic action is in principle always 'embedded' in some form or another of social structure” (p. 28). On both views, "structures” are positions created by the distribution of the relational ties between actors (Schweizer, 1997, p. 751) and are "a result of rules and resources that exist in and through the activities of human agents” (Miller \& Rivera, 2007, p. 144). In other words, as Coleman (1990) put it, “Granovetter's notion of embeddedness may be seen as an attempt to introduce into the analysis of economic systems social and organizational relations” (p. 302).

Indeed, Granovetter's (1973, 1983) earlier work on network ties formed a constitutive part of his embeddedness theory, in that networks, and thus economically embedded social actions, result either from "strong" ties, which generally signify intensive but narrowly bounded relationships and opportunities, or from "weak" ties, whereby a broader range of information and opportunities inhere to more distant relationships or 
contacts. Illustrating this from the perspective of the job seeker, strong ties might consist of neighbors and/or social groups that would be likely to provide overlapping and thus limited information about job possibilities, whereas weak ties, such as staff in job training or workforce organizations or persons whose networks radiate out to multiple distant contact points, potentially provide a new and expanded landscape of job possibilities.

Further, economic sociologists have recently extended Granovetter's tie concept through attention to the content or quality of the ties as well as to the structures formed by the ties (Krippner \& Alvarez, 2007): in particular, the emotional valence in, level of trust fostered by, and quality of information transferred through the tie relationship. Zelizer (2002) also extended Granovetter's tie concept, holding that people differentiate among particular kinds of interpersonal relations, which in turn form different practices, rights and obligations, or "differentiated" ties. Similarly, Hurlbert, Haines, and Beggs (2000) extended Granovetter's work on social network resources with the question, "how do individuals, in response to a particular event, choose to activate particular sectors of the multiple networks in which they are embedded" (p. 599). These extensions mean that a weak tie, such as an organization in a workforce intermediary's network, needs its staff to develop personal relationships with the job seeker or with another organization's staff, needs to provide consistent service in order to be perceived as trustworthy, and needs to offer high-quality and differentiated contacts to be an effective choice for the job seeker or organization.

Equally important, although Granovetter's network tie concept has been characterized as the same as "social capital," the two concepts are both similar and different. Although both concern economic phenomena and both "inhere in the structure of relations within which purposive action takes place” (Portes \& Sensenbrenner, 1993, p. 
1322), social capital relationships are more commonly dyadic and linear, whereas network ties are more likely to be multiple and concurrent. In addition, early theorizing about social capital presented it as solely positive, whereas some later versions and most conceptualizations of network ties identify the potential for both positive and negative valences and outcomes. Following Granovetter, the concept of network ties rather than social capital is used in this article.

In all, Granovetter tried to show theoretically that economic behavior involved more than rational choices by atomized, independent actors. On his view, economic action and decision-making occurred through, as Lazer (2006) put it, "relational ties and one's structural position in a network of personal contacts” (p. 1). As a result, Granovetter's conception of embeddedness has generally been applied at micro and meso levels; that is, at individuals and organizations as they "mediate the effects of macroscopic processes” (Zukin \& DiMaggio, 1990, p. 3). The exploration and discussion in this article follows in that direction.

Importantly, while Granovetter's (1985) formulation of embeddedness is considered seminal, it is not without critique, which has charged incomplete development of the concept at the macro or market/economy level (Barber, 1995; Krippner \& Alvarez, 2007), the ambiguity, varied uses, and often insufficient specification of the term (Moody \& White, 2003; Portes \& Sensenbrenner, 1993), and its exclusive reliance on networks (Swedberg, 1997). As the exploration in this article directly concerns micro and meso rather than macro levels, that aspect of the critique may be less relevant. Regarding ambiguity, however, in this article we strive for specificity and consistency in our use of the term. Arguably, the recent extensions to embeddedness theory noted earlier have deepened its potential relevance to the Hurricane Katrina- 
New Orleans situation, as will be illustrated in the family experiences which follow the brief discussion of research procedures and pre-Katrina New Orleans next.

\section{Empirical and Spatial Context of the Ethnographic Research in New Orleans}

Research Procedures

Between 1998 and 2003, the principal investigator (first author) and her team of eight local researchers, which included the second author, conducted ethnographic research in five U.S. cities - one of which was New Orleans. In order to better understand the mobility efforts of low-income families (commonly called "the working poor") under economically challenging urban conditions, the team identified a set of "key parents" who had participated in job training programs affiliated with a national workforce demonstration program and followed them for up to five years (see Iversen \& Armstrong, 2006, for complete description of research methods). In each city, a designated workforce intermediary organization (Giloth, 2004) strove to develop seamless networks of employmentrelated education, training and service organizations, policymakers, and community members to foster the economic well-being of families and communities. The New Orleans workforce intermediary also conducted a four-week pre-employment program, which the study participants attended.

Using formal and informal interviews and observation in the families' natural settings (Denzin \& Lincoln, 2005), the team spent time in the families' homes, neighborhoods and extended family networks, and also in the parents' job training sites, community organizations, firms and children's schools. The research design overall was similar to Duneier's (1999) extended place method, Marcus's (1998) multisited ethnography, and Burawoy's (2003) reflexive ethnography. In the explicit attempt to link micro 
with macro processes (Burawoy et al., 2000; Willis, 2000), these methods of inquiry begin with a core place or person and fan out organically to those in contact with, mentioned by, and relevant to the core per-son(s) along the dimension of interest. "Fanning out" enabled us to contact over 1,000 auxiliary persons and organizations associated with the families in the five cities-around 200 in New Orleans alone.

The audiotaped and transcribed material was analyzed qualitatively by multiple analysts, first through the creation of computer-assisted coded themes and then through the construction of individual family stories according to a diachronic narrative approach (Ostrander, 1995), or telling a story through time. Demographic data on the key parents from training program administrative records (Hebert et al., 2002) was compared quantitatively with the same data collected on the other 4,000 workforce demonstration participants who found jobs after their training program. Parent characteristics were also compared with those of recipients of Unemployment Insurance (Needels, Corson, \& Nicholson, 2001) and Temporary Assistance for Needy Families (U.S. Department of Health and Human Services, 2001), which became the safety net programs after the welfare reform legislation of 1996. These comparisons suggested that the study sample was substantively similar to millions of low-earning families across the United States.

Although the original ethnographic research formally ended in mid-2003, the authors spent a week in New Orleans in February 2006 to explore what might lie ahead for the research families if they were to return to the city. We conducted observations and interviews with former and new research participants, some of which continued periodically thereafter. While the original research was loosely guided by a systems perspective on the interrelationships between persons/ families and 
organizations, reanalysis of what the workforce intermediary network meant and resulted in for the job training participants and their families suggested that network ties were a critical aspect of their mobility process, for good and ill. Alternative explanations cannot be fully ruled out, however. For example, some scholars working in an embeddedness tradition in anthropology have conceptualized systems and subsystems as "sets of embedded networks” (Wolfe, as cited in Schweizer, 1997, p. 775), rather than as different ways to conceptualize social action, as this article does. That said, triangulation of researchers, respondents, and analysts, which included families' review of their narratives, or what Burawoy (2003) called "valedictory revisiting," increased the authenticity of the findings and credibility of the interpretations (Padgett, 2008).

\section{Pre-Katrina New Orleans ${ }^{1}$}

The spatial context for examining a sociological embeddedness perspective on a disaster situation concerns the economic environment for the research families and thousands like them in New Orleans before as well as after Hurricane Katrina. Regarding its workforce, the city of New Orleans had lost 18\% of its population between 1970 and 2000 (Muro et al., 2005, p. 4), and an additional 1\% between 2000 and July 2005 (Liu \& Plyer, 2008, p. 11). Regarding job opportunities, New Orleans's share of metropolitan area jobs had dropped from 66\% in 1970 to $42 \%$ in 2000 , and the remaining jobs shifted from the higher-wage manufacturing sector to the lower-wage service and retail sectors (Muro et al., 2005). Nearly 87\% of the jobs for all New Orleanians were in the service

\footnotetext{
${ }^{1}$ All data about New Orleans in the paper pertain to Orleans Parish alone, and not to the New Orleans metropolitan region, which includes parishes less harmed by the Hurricane Katrina situation. Orleans Parish and the city of New Orleans are the same demographic and geographic entity.
} 
sector, and in 2003 the average annual pay in half of those jobs fell below the national average (Muro et al., 2005). Even in the few higher-paying industries in New Orleans, wage levels were not robust. The national average weekly wage in private industry in 2000 was $\$ 648$, which was $13.1 \%$ higher than the comparable wage in New Orleans (Dolfman, Wasser, \& Bergman, 2007, p. 5). More generally, a long history of inadequate public transportation (Taylor, 1984), especially outside the tourist areas, plus a weak educational system that Plaisance (2006) characterized as "one of the nation's worst," not only limited access to existing jobs but also discouraged industrial development. The families' employment efforts were thus embedded in a shrinking economic context, as their lived experiences suggest.

\section{An Embeddedness Perspective and Families' Lived Experience}

Narrative material ${ }^{2}$ from the New Orleans families seemed to illustrate how the network aspects of embeddedness theory-network structures and network ties, as evidenced particularly in the form of the workforce intermediary and its relational network - constituted the pre-Katrina economic conditions in New Orleans in which the families' post-Katrina economic potential is embedded.

These examples are only three of many.

\section{Elizabeth Seabrook}

Thirty-seven-year-old Elizabeth Seabrook had been employed as a certified nursing assistant for many years,

\footnotetext{
${ }^{2}$ All person names are pseudonyms chosen by the families. Pseudonyms for auxiliary persons and organizations were chosen by the authors.
} 
but found over time that she couldn't support her two preschool-aged children on that income and thus sought a more financially and personally rewarding career. In 2000, she enrolled in the New Orleans workforce intermediary's pre-employment program, whose administrators had developed and nurtured network ties with a local community college, which enabled Elizabeth to enroll in the college's medical technology training program. Despite the welldeveloped community college ties, the network might have better facilitated Elizabeth's success if it had also fostered ties with secondary education institutions.

Indeed, the medical technology program was designed to be 18 months long, but even before the storm, Elizabeth had been a full-time student for over three years. In 2002, a college administrator told the research team that Elizabeth was required to enroll in mostly remedial subjects, in part because the high school education she received in New Orleans public schools had been substandard in quality. Illustrating this, at least $41 \%$ of fourth-graders and at least $59 \%$ of eighth-graders in New Orleans failed the standardized Louisiana Educational Assessment Program [LEAP] test in 2002-2003 (Nelson, 2003). Although remedial courses are prevalent among community college students across the United States (Schemo, 2006), the inadequacy of Elizabeth's earlier schooling, despite the fact that she'd earned excellent high school grades, severely constrained her progress. The other constraint on Elizabeth, and on prior training program graduates in the medical program, was the problem of incomplete information exchange in the college-intermediary network, as the college administrator described:

The pre-employment program graduates at the Community College campus are typically not 'college literate.' I don't think the problems arose entirely out of academic incompetence. In fact, the [intermediary] program grads generally matched the college norm in terms of background and testing ability. Most students were in college for the first time and $80 \%$ of those in health areas began in remedial 
coursework for at least one subject. I feel that the problems are more systemic, mainly concerning communication breakdowns in the areas of recruitment and admissions. And in my opinion, the program staff lack a working knowledge of the college's regimented testing procedures, which also caused stumbling blocks. Community College administrator, fall 2002

In addition, education policy in the early 2000s was not attuned to students like Elizabeth. In order to be eligible for the total allotment of federal education funding for training like the medical technology program, the student must attend school full time. However, Elizabeth often held three jobs simultaneously in order to support her family, which left little time for the amount of studying required of a fulltime student. Thus, Elizabeth not only had to take remedial courses, she had to repeat courses that she failed because she didn't have enough time or energy to study. One of Elizabeth's more desperate strategies to succeed against such odds was to listen to lesson tapes through headphones while she slept. To compensate for such challenges, some intermediaries in other cities used their network relationships to embed on-site mentoring of students or new workers in their vocational institutions or businesses, which increased the level of trust and quality of information exchanged. However, this action was absent in the New Orleans network, as an intermediary administrator lamented:

The Community College's curriculum requirements were problematic. At the pre-employment program, we originally expected that the college would cater to program graduates. However, the requirements of licensure state certification and exams proved to be too cumbersome for an established and relatively entrenched institution, and as a result the college was unable to accommodate program grads by customizing their programs. Consequently, our students were unable to register for technical courses, and as a result upwards of 60 percent were dropping out. Intermediary administrator, winter 2002

Elizabeth's intermediary's network would also have been strengthened by more robust ties to subsidized, quality 
child-care facilities. In Elizabeth's experience, center-based care was either affordable but poor quality (in one site, her children were never allowed outside) or higher quality but unaffordable. Thus, in order to meet the multiple demands

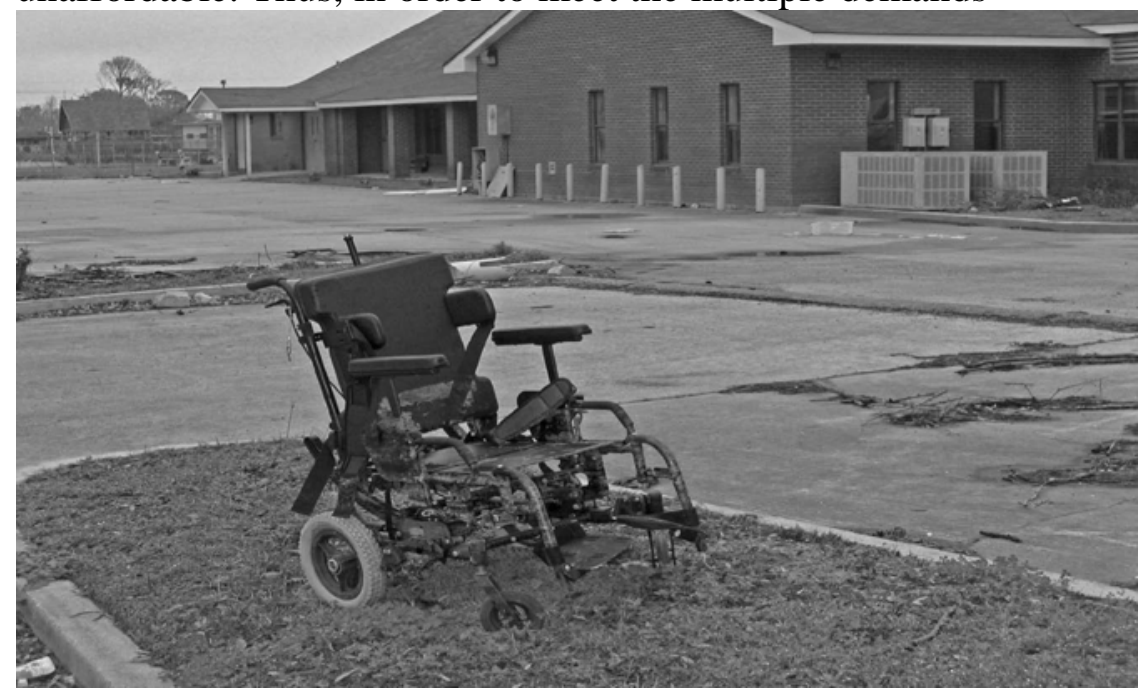

Fig. 1. Grounds of Elizabeth Seabrook's mother's senior care housing facility, February 2006.

of work, school, and parenting, Elizabeth depended extensively on her aging, chronically ill mother for beforeand after-school help with the children. Although postKatrina child-care assistance has been characterized as more flexible and accessible than earlier (Louisiana Department of Social Services, 2008), a workforce network would need to ensure that sufficient slots were available for returning families. As of April 2008, only about two in five (41\%) of former child-care facilities in Orleans Parish had reopened (Liu \& Plyer, 2008, p. 50).

Three years post-Katrina, we still don't know where Elizabeth, her children or her mother are, or how they are faring. Chronically ill elderly persons in senior care facilities, such as Elizabeth's mother, seemed forgotten both during and after Katrina, as the abandoned wheelchair in front of the mother's abandoned facility portrays (Figure 
1). We do know, however, the Elizabeth and her family were embedded in a deeply inadequate economic infrastructure in New Orleans long before the hurricane, and that despite its aims and community college ties, the network at that time was not sufficiently developed to compensate for the missing ties. While Elizabeth's network situation lacked education and child-care coherence, Rachel Quinn’s lacked employment attunement.

\section{Rachel Quinn}

At age 40, after two-plus years of post-secondary education, no degree, and a series of short-term jobs, Rachel Quinn enrolled in construction training to improve her career path and try to move her family out of public housing. She had already enhanced her two teenaged children's futures by navigating their enrollment in specialized high schools far from the family's high-poverty neighborhood because their neighborhood high school was rated "unacceptable" by state standards (Louisiana Department of Education, 2001). In spring 2006, as Rachel reported from her displacement city on the East Coast, her son was in college and her daughter was advancing in military service.

Earlier, after completing the workforce intermediary's fourweek pre-employment program, Rachel was hired by a construction labor union that was part of the intermediary's network, and "on paper" she earned a family-sustaining income. However, Rachel was channeled into event carpentry rather than residential or commercial carpentry, which meant that she constructed temporary displays and booths for conventions, conferences, and large product shows. Even before the hurricane, there wasn't enough business to keep all the event carpenters fully employed, as Rachel's supervisor related:

Only about one hundred of the two hundred and fifty to three hundred union members at trade show sites work a full forty-hour work week. Rachel Quinn's construction union supervisor, 2003. 
Consistent with the supervisor's comments, although Rachel technically held a full-time job, she was only assigned part-time work. This also meant that her projected annual income of $\$ 28,204$ only resulted in about $\$ 6,000$. Moreover, the potential work environment for Rachel in post-Katrina New Orleans reflected its embeddedness in the state of the industry before Katrina. Six months after the storm, Rachel's former supervisor described the debilitated construction market for locals:

Some carpentry work is available for residential facilities, but there isn't any yet for commercial facilities. This is partly because very few journeymen have returned to the city and electrical outages are continual ...In addition, the Hispanics came and got all the early construction work. Rachel Quinn's construction union supervisor, February 2006

The supervisor's final comment was, in fact, an accurate reflection of the early post-Katrina demography in New Orleans, as Maruyama and Ruscher (2006) reported: "Approximately half of the reconstruction workforce in Orleans metropolitan area is Latino, and approximately half of these individuals are undocumented workers. The vast majority (87\%) relocated from another location elsewhere in the United States where they had lived prior to Katrina" (p. 257). Two years after Katrina, the demographic shift to a higher proportion Hispanic and a lower proportion African American persisted (Plyer, 2007). Thus, because trade show construction was so limited, if Rachel returned to New Orleans, she would have to remain in public housing - if it were available.

In reality, even before Katrina, Housing Authority of New Orleans (HANO) officials had discussed converting Rachel's development into mixed-income housing, which is a trend seen nationally (Ouroussoff, 2006). An earlier public redevelopment project in New Orleans resulted in about 25\% low-income units and 75\% 
market-rate units, which meant that only about 70 of the 800 low-income families who previously lived there, fewer than one in 10, were able or eligible to return (Kamenetz, 2005). Although a grass-roots coalition of former residents and New Orleans advocates actively contested the city's public housing demolition and rebuilding plans (Cacibauda, 2007), and Rachel's development was part of the intermediary's network, both sets of relationships consisted of strong rather than weak ties, which meant they were constrained in their impact on broader housing conditions. In fact, as the barbed wire fence in the 2006 photo portended (Figure 2), demolition of Rachel's former development began in December 2007 (Ouroussoff, 2007), adding to the $60 \%$ reduction in the city's public housing stock (Lehrer, 2008). Thus, while the intermediary's weak

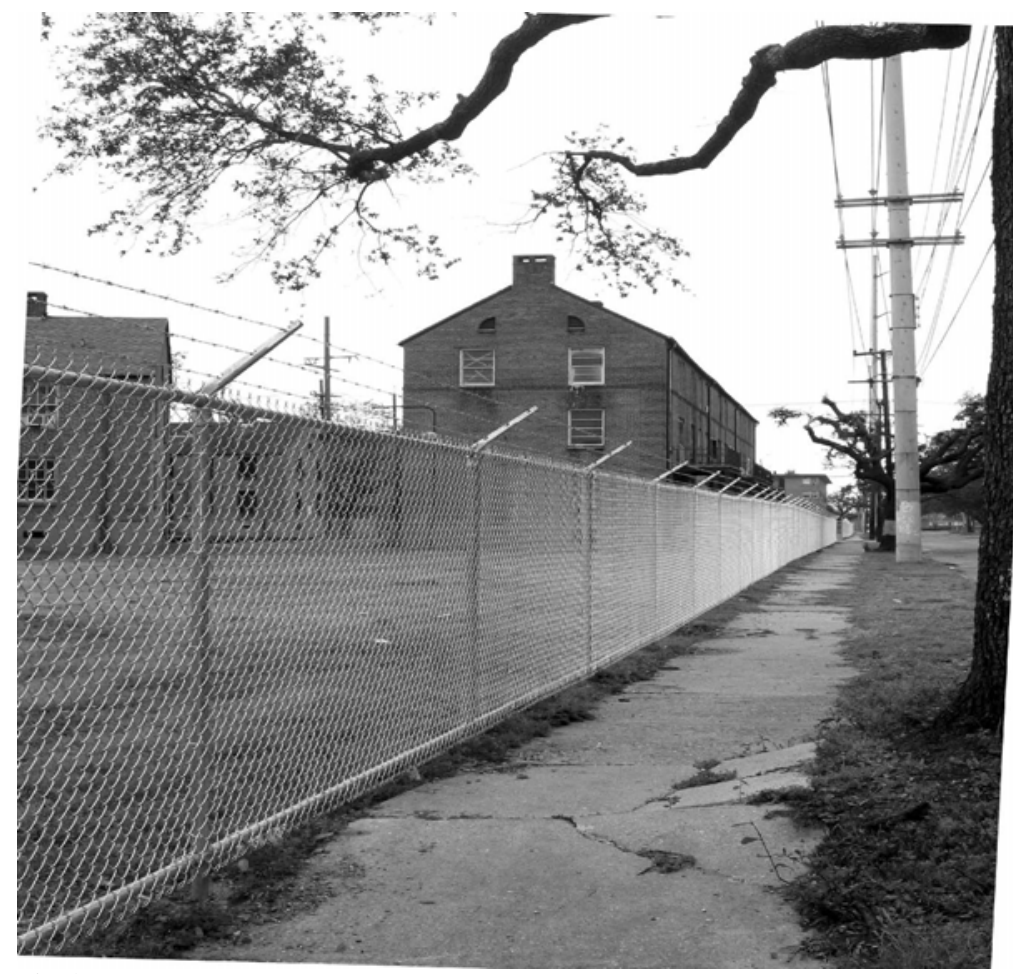

Fig. 2. Rachel Quinn's public housing development, February 2006. 
tie to the construction union facilitated Rachel's original employment, the quality of the tie and of her job was inadequate. As a result, Rachel was unable to move forward economically or out of public housing pre-Katrina, and now both mobility avenues seem closed. Last, Joseph Faithful experienced an inadequate weak-tie network, which he replaced with a strong-tie network that seemed beneficial for the short run, but limited for the long run.

\section{Joseph Faithful}

In the early 2000s, Joseph Faithful's family's church took on an "informal" intermediary role in joining families, skill training, and jobs in a seamless network of strong ties. In this case, strong ties seemed surprisingly beneficial, much as they have been for many immigrant enclaves (Portes \& Sensenbrenner, 1993), likely because the marginalized position of both Joseph and immigrant groups meant that weaker ties were less readily available to them.

Alternatively, the benefits of the strong ties were illusory.

Joseph was a 23-year-old high school graduate and a married father of two infant children. He had earlier, and passionately, pursued a construction career through the New Orleans workforce intermediary's construction apprenticeship program, but the program lacked reciprocity with the intermediary such that Joseph's only assignment in the first days of the apprenticeship was to pick up trash. Holding that he "did not go to all this training and take two [unpaid] months out of my life so that I could go pick up trash," Joseph left the apprenticeship for a job outside the construction field in order to support his family, and severed his relationship with the intermediary and its network. In response to this particular event, as Hurlbert, Haines, and Beggs (2000) would have described, Joseph activated the family's church as his "official” workforce network. 
As a strong tie, the church offered emotional and instrumental support for Joseph's work efforts.

Emotionally, the church was "family," as both Joseph and his wife were partially estranged from their families of origin. Instrumentally, because the church served as the umbrella for an informal construction business, Joseph found construction employment and mentoring with George, a trusted church colleague who was a selfemployed contractor. While Joseph's income arrangement with George was under-the-table, raising the question of whether staying with the construction apprenticeship might have been more economically productive, Joseph valued the encouragement and breadth of experience he gained under George's tutelage. Still, had Joseph remained in the workforce network's apprenticeship and moved up in union ranks, weak ties to the industry's multi-state resources might have benefited him during displacement after the hurricane.

Alternatively, the fact that the church operated satellites in several different parts of New Orleans meant that it could potentially remain a useful intermediary after Hurricane Katrina - at least to the extent that the church's network as a whole remained functional. Although, to our knowledge,
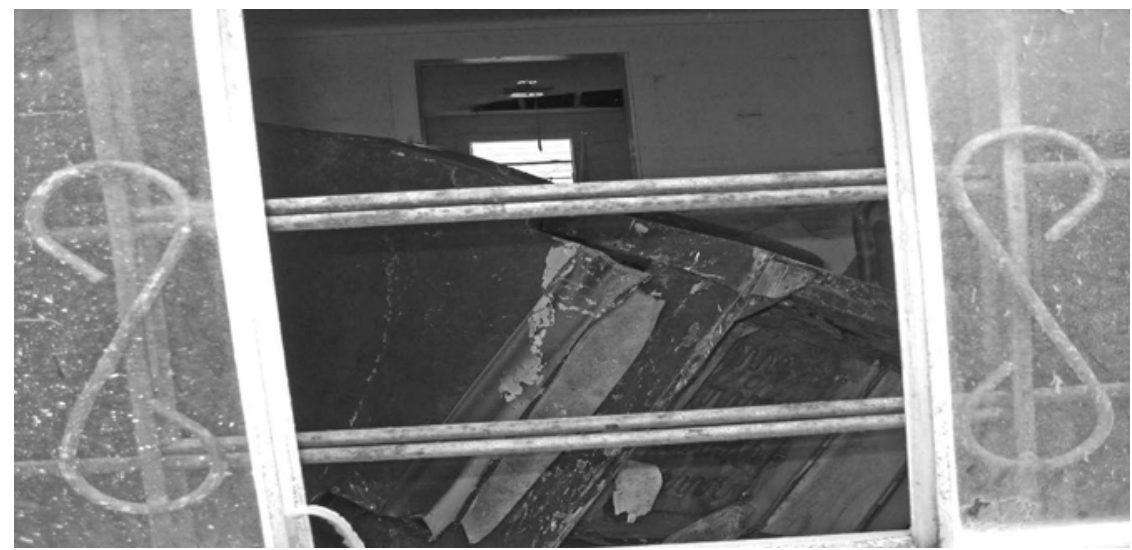

Fig. 3. Joseph Faithful's former living room, Lower Ninth Ward, February 2006. 
by spring 2006, Joseph and his family had not returned to New Orleans, the local researcher reported that the church had set up residential construction work in one of its lessdamaged satellites such that it continued to be a source of economic and social support for its remaining parishioners. Other than this hub, however, as Rachel Quinn's supervisor had reported, residential construction work in post-Katrina New Orleans was rare.

Moreover, the house in the Lower Ninth Ward that George owned and rented to Joseph and his family before Katrina was completely demolished by the storm, as the picture of the former living room shows (Figure 3). Thus the constricted opportunity for Joseph Faithful in today's New Orleans seemed to reflect that sole reliance on strong ties might not have been the most economically productive pathway for him in the long run.

\section{Furthering a Sociological Embeddedness Perspective for Disaster Research and Policy}

The narratives of Elizabeth, Rachel, Joseph, and a few of the 200 auxiliary contacts from our ethnographic research in New Orleans, suggest that even before Hurricane Katrina, the economic environment in the city only minimally supported the productivity of families headed by lower earners. The limited economic (i.e., educational, housing, employment, and work support policy) infrastructure in which these families had been embedded for decades was surely worsened but not caused by Katrina. Nevertheless, the focus of most public discourse and social action after Katrina has been on remedies to particular technological, geophysical or political aspects, such as communications systems, levee reconstruction, or government disaster planning and responses.

This contrast between constitutive and particularistic orientations to the social milieu reminds us that 
conceptualizing and defining a phenomenon is far more than linguistic, as Perry (2005) and Quarantelli (2005, 2006) contended as well. Conceptualizing the Hurricane Katrina-New Orleans situation as "natural" or as an anomalous "event" has obscured the fact that it is equally viable to conceptualize such a disaster situation as embedded economic choices over time and throughout a society. As the empirical examples from the pre-and postKatrina ethnography suggest, a sociological embeddedness perspective on disaster situations seems highly congruent with families' lived experience; in particular, the obvious and dynamic seamlessness of past, present and future economic contexts and social actions.

As such, a more intensive and extensive incorporation of the sociological concepts of embeddedness (Granovetter, 1985; Krippner et al., 2004) and "weak," "strong," and “differentiated” network ties (Granovetter, 1973; Hurlbert, Beggs, \& Haines, 2006; Zelizer, 2002), may provide a generative direction for theory building among disaster scholars as they harness and expand upon many rich contributions from multiple disciplines. In particular, Elizabeth's, Rachel's, and Joseph's very typical stories about trying to move ahead through training and better jobs underscore that the strength, content, and quality of different ties are all critical components of an effective workforce network. Accordingly, attention needs to be paid not only to which network ties are activated, but also to how they are cultivated in the social environment over time.

At base, an embeddedness perspective converts the macro and micro from binaries to the notion of a fluid and dynamic continuum of social actions, which, in addition to guiding theory, provides openings for more inclusive social planning and policy directions. Illustrating a similar step, Trigilia (2007) stressed that a network of relations between individuals and a network of relations between 
organizations or collective actors are both important: “A good network of relations between interest organizations, financial institutions, universities and local governments [in effect, 'weak' ties] can favor the improvement of infrastructural facilities and the efficient provision of economic and social services, as well as ...the establishment of effective cooperation between economic actors and research and training institutions” (p. 69). Planning, policy, and research implications of an embeddedness perspective for post-Katrina New Orleans follow along similar lines.

Beginning with neighborhood and community planning for New Orleans, network tie concepts might be usefully incorporated into an existing risk assessment protocol such as the Social Vulnerability Index (SoVI) (Cutter et al., 2003; Cutter \& Emrich, 2006), which reveals spatial as well as temporal differences in social vulnerability according to a broad set of demographic and environmental actions and actors. Used ground-up by community networks coordinated by workforce intermediaries (Giloth, 2004) or by faith-based intermediaries (Holcombe, 2007), versus solely top-down, which as anthropologists Breunlin and Regis (2006) described, "disproportionately impact black and low-income communities in New Orleans” (p. 744), an enhanced SoVI assessment might help Elizabeth, Rachel, Joseph and others like them to identify the unique roles and resources that each type of tie relationship in or available to their network could contribute to strengthening their general, everyday lives. At the same time, developing different network ties could strengthen and enhance individual and organizational hurricane evacuation decisions, dislocation responses, or recovery strategies. As one example, illustrated in both Rachel's and Joseph's narratives, pre-Katrina assessment of the structure and quality of their tie relationships could have identified what emotional and instrumental support networks were available as well as what disadvantages might inhere to exclusive reliance on them. Post-Katrina and for the future 
more generally, an enhanced SoVI or similar assessment could help Joseph identify and engage additional weak tie relationships, such as potentially fruitful employment, housing or relocation contacts and resources. Similar assessment could help Rachel build a network of weak tie relationships that might buffer and provide alternatives to her conflicting work and housing contexts.

More broadly, assessment of network ties through an enhanced vulnerability protocol could be aimed at more inclusive and potentially more effective infrastructure planning in New Orleans-what traditional disaster scholars call "strengthening," both for preventive mitigation of disaster effects and for increased resilience in recovery and to establish a stronger economy for the future (Berke \& Campanella, 2006; McEntire, Fuller, Johnston, \& Weber, 2002). Such planning could engage community members in natural neighborhood groups such as community centers, faith organizations, or workforce intermediaries with broader organizational and institutional networks, and lead to more participatory decisions and actions that would be actively sustained over time.

Organizing networks around such localized groups has a good chance of being effective in New Orleans because of the city's long tradition of ward and neighborhood identification. For example, Capowich and Kondkar (2007) reported that after a series of neighborhood planning meetings about rebuilding New Orleans neighborhoods took place, the process of combining these plans into district-level project proposals had begun (p. 185). "Maximum participation by the entire community" (Costanza et al., 2006, p. 319) has been viewed by many as critical for the viable future of New Orleans, as this and other research (Ethridge, 2006; Hartman \& Squires, 2006) contend as well. In other words, "the focus should be on local preferences and local knowledge” (Kiesling \& Irons, 2005, p. 3), with all their inherent and potentially 
generative differences, and explicitly not on a uniform, one-size-fits-all design.

Another benefit of a neighborhood/community-based SoVI extension is that regardless of the divisions that exist in a locale by class, race, risk (Beck, 2006) and the like, as Elliott and Pais (2006) reported, "people respond to disasters not as isolated individuals but as members of overlapping forms of social affiliation, which interpret, affirm and support particular definitions and responses to the situation” (p. 300), or as Breunlin and Regis (2006) put it, the role of people [i.e. through network ties] "is as a platform for reproducing life in the city” (p. 761). Thus, an extended SoVI-type assessment could be made relevant to residents of all economic strata, as well as to the varied organizations with which they are or could be involved.

In the policy domain, community-generated knowledge might lead to policies that are guided by a multifaceted, multilevel vision of economically embedded social action. The crafting of integrated health, housing and employment support policies, among others, could actualize such a vision. As a small example, the recent increase in the maximum Pell grant (Schemo, 2007) was a policy direction that could help family heads like Elizabeth Seabrook meet the intersecting and competing demands of education, work and family life, not only before, but also during and after a Hurricane Katrina-New Orleans situation. Thinking of education, job training, employment, and policy, for example, as embedded in families' economic actions might help to break down and ultimately eliminate some of the bureaucratic organizational boundaries that have constrained mobility for families like those in this research, and more generally, that have perpetuated stratification and class division.

In terms of scholarly inquiry, further theoretically based research could enhance knowledge building about 
embeddedness and disaster situations, generally and specifically for New Orleans. For example, because the exploration and resultant theorizing about embeddedness in this article derived in part from reanalysis of existing empirical material, a next step would be to use an embeddedness network perspective in the design of original field research (Schweizer, 1997). Schweizer called particularly for longitudinal examination of network studies of social organizations (p. 756), which would certainly include intermediary networks, and by definition, network assessment would involve human and organizational or institutional actors. As such, longitudinal research on the enhanced social vulnerability protocol suggested earlier could reveal prospectively how differently each of the New Orleans families in this research might fare during a situation involving a hurricane, as well as what networked personal, policy and organizational ties each would need in order to construct new economic futures thereafter.

Future research could also valuably pursue the relevance of embeddedness and network concepts in other parts of the world that experience disaster situations similar to Hurricane Katrina-New Orleans. For example, Caporale's (2000) study of rainstorm-related landslides in Italy in 1998 and Donohue, Masileia, and Gears' (2000) report about flood devastation in South Africa in 2000 revealed important parallels to the continuing danger in New Orleans from the inadequate preventive and responsive measures provided by all levels of government. Crosscultural knowledge building, as disaster anthropology has valuably shown (Oliver-Smith, 1996), is a potentially rich learning and planning strategy. As evidence, Wisner (2001) reported that community-based social vulnerability assessments have emerged in countries outside the United States, whereby "the community defines its own vulnerabilities and capabilities; outsiders don't” (p. 5). 
More broadly, varied conceptual approaches to disaster situations, such as systems, social vulnerabliity, and embeddedness, could be compared within the United States and across cultural domains, without losing sight of what is sociologically useful (Stallings, 2002, p. 284). In this case, additional examples and deeper understanding of the economic embeddedness of disaster situations such as Hurricane Katrina-New Orleans would be sociologically useful. For example, because application of the findings and perspective in this article are limited to the Hurricane Katrina-New Orleans situation, broader inquiry could potentially ascertain whether the current findings are relevant to other types of disaster situations or to similar types of disaster situations in other geographic and cultural milieus. Ultimately, research and planning deriving from a sociological embeddedness perspective on disaster situations such as Hurricane Katrina-New Orleans seem to constitute both an essential step toward greater societal economic well-being and an ongoing charge to those trying to build a more just, inclusive world.

\section{References}

Alexander, D. (2006). Symbolic and practical implications of the Hurricane Katrina disaster in New Orleans. Social Science Research Council. Retrieved July 13, 2007, from http://understandingkatrina.ssrc.org/Alexander/printable.ht $\underline{\mathrm{ml}}$

Achenbach, J. (2008). Man to blame for Iowa flooding? The Washington Post. Retrieved June 19, 2008, from www.msnbc.com/id/25254541/

Barber, B. (1995). All economies are "embedded": The career of a concept, and beyond. Social Research, 62(2), 387-413. 
Barnshaw, J., \& Trainor, J. (2007). Race, class, and capital amidst the Hurricane Katrina diaspora. In

D. L. Brunsma, D. Overfelt, \& J. S. Picou (Eds.), The sociology of Katrina: Perspectives on a modern catastrophe (pp. 91-105). Lanham, MD: Rowman \& Littlefield.

Beck, U. (2006). Living in the world risk society. Economy and Society, 35(3), 329-345.

Berke, P. R., \& Campanella, T. J. (2006). Planning for postdisaster resiliency. Annals of the American Academy of Political and Social Science, 604, 192-207.

Breunlin, R., \& Regis, H. A. (2006). Putting the Ninth Ward on the map: Race, place, and transformation in Desire, New Orleans. American Anthropologist, 108(4), 744-764.

Brunsma, D. L., Overfelt, D., \& Picou, J. S. (2007). The sociology of Katrina: Perspectives on a modern catastrophe. Lanham, MD: Rowman \& Littlefield.

Burawoy, M. (2003). Revisits: An outline of a theory of reflexive ethnography. American Sociological Review, 68, 645-679.

Burawoy, M., Blum, J. A., George, S., Gille, Z., Gowan, T., Haney, L., et al. (2000). Global ethnography: Forces, connections, and imaginations in a postmodern world. Berkeley: University of California Press.

Cacibauda, D. M. (2007). Public Meeting re: “X” Housing Development. Verbatim court report of Section 106 consultation meeting, New Orleans, LA: Housing Authority of New Orleans. 
Caporale, R. (2000). The May 1998 landslides in the Sarno area in Southern Italy: Rethinking disaster theory.

Retrieved July 13, 2007, from

http://www.colorado.edu/hazards/research/qr/qr131/qr131.

$\underline{\mathrm{html}}$

Capowich, G. E., \& Kondkar, M. M. (2007). Rebuilding New Orleans neighborhoods after Hurricane Katrina:

Toward a theory of social structure and cultural creativity. In D. L. Brunsma, D. Overfelt, \& J. S. Picou (Eds.), The sociology of Katrina: Perspectives on a modern catastrophe (pp. 173-190). Lanham, MD: Rowman \& Littlefield.

Clarke, L. (2007). Postscript: Considering Katrina. In D. L. Brunsma, D. Overfelt, \& J. S. Picou (Eds.), The sociology of Katrina: Perspectives on a modern catastrophe (pp. 235-241). Lanham, MD: Rowman \& Littlefield.

Coleman, J. S. (1990). Foundations of social theory. Cambridge, MA: Belknap.

Colten, C. E. (2006). Vulnerability and place: Flat land and uneven risk in New Orleans. American Anthropologist, 108(4), 731-734.

Cooper, C., \& Block, R. 2006. Disaster: Hurricane Katrina and the failure of Homeland Security. New York: Henry Holt and Company.

Costanza, R., Mitsch, W. J., \& Day, J. W., Jr. (2006).

Creating a sustainable and desirable New Orleans.

Ecological Engineering, 26, 317-320.

Cutter, S. L. (2005). Are we asking the right question? In R. W. Perry \& E. L. Quarantelli (Eds.), What is a disaster?: New answers to old questions, (pp. 39-48). Philadelphia: Xlibris. 
Cutter, S. (2006). The geography of social vulnerability: Race, class, and catastrophe. Retrieved May 10, 2008, from http://understandingkatrina.ssrc.org/Cutter

Cutter, S. L., Boruff, B. J., \& Shirley, W. L. (2003). Social vulnerability to environmental hazards. Social Science Quarterly, 84(2), 242-261.

Cutter, S. L., \& Emrich. C. (2006). Moral hazard, social catastrophe: The changing face of vulnerability along the hurricane coasts. Annals of the American Academy of Political Science, 684, 102-112.

Denzin, N. K., \& Lincoln, Y. S. (2005) 'Introduction,' In N. K. Denzin \& Y. S. Lincoln (Eds.), Handbook of qualitative research (3rd ed., pp. 1-32). Thousand Oaks, CA: Sage.

Dolfman, M. L., Wasser, S. F., \& Bergman, B. (2007). The effects of Hurricane Katrina on the New Orleans economy. Monthly Labor Review, 130(6), 3-18.

Donohue, S., Masilela, T., \& Gear, J. (2000). Disaster management. In A. Ntuli (Ed.), South African health review, (pp. 455-465). Zaire, South Africa: Health Systems Trust.

Duneier, M. (1999). Sidewalk. New York: Farrar, Straus and Giroux.

Dynes, R. R., \& Rodríguez, H. (2007). Finding and framing Katrina: The social construction of disaster. In D. L. Brunsma, D. Overfelt, \& J. S. Picou (Eds.), The sociology of Katrina: Perspectives on a modern catastrophe (pp. 2333). Lanham, MD: Rowman \& Littlefield. 
Elliott, J. R., \& Pais, J. (2006). Race, class, and Hurricane Katrina: Social differences in human responses to disaster. Social Science Research, 35, 295-321.

Enarson, E. (2006). Women and girls last?: Averting the second post-Katrina disaster. Retrieved May 10, 2008, from http://understandingkatrina.ssrc.org/deWaal/printable.html

Erikson, K. (2006). Disaster, environment and social order: Reflections on Katrina. Gaylord Nelson Retrospective Lecture Series. Retrieved March 30, 2008, from http://www.nelson.wisc.edu/legacy/lectures/erikson.doc

Erikson, K. (2007). Foreword. In D. L. Brunsma, D. Overfelt, \& J. S. Picou (Eds.), The sociology of Katrina: Perspectives on a modern catastrophe (pp. xvii-xx). Lanham, MD: Rowman \& Littlefield.

Ethridge, R. (2006). Bearing witness: Assumptions, realities, and the otherizing of Katrina. American Anthropologist, 108(4), 799-813.

Friedman, P. \& Relave, N. (2005). Managing in emergencies. Strategy Brief . Washington, DC: The Finance Project.

Gilman, N. (2006). What Katrina teaches about the meaning of racism. Social Science Research Council. Retrieved July 13, 2007, from http://understandingkatrina.ssrc.org/Gilman/printable.html

Giloth, R. (Ed.). (2004). Workforce intermediaries for the twenty-first century. Philadelphia: Temple University Press in association with The American Assembly, Columbia University Press.

Gist, R., Lubin, B., \& Redburn, B. G. (1998). Psychosocial, ecological, and community perspectives on disaster 
response. Journal of Personal \& Interpersonal Loss, 3(1), 25-51.

Gordon, M. (2007). Scientists point out missed chances with rebuilding efforts could hamper flood protection. The Times-Picayune. Retrieved July 23, 2007, from http://www.nola.com

Granovetter, M. (1973). The strength of weak ties. American Journal of Sociology, 78, 1360-1380.

Granovetter, M. (1983). The strength of weak ties: A network theory revisited. Sociological Theory, 1, 201-233.

Granovetter, M. (1985). Economic action and social structure: The problem of embeddedness. American Journal of Sociology, 91, 481-510.

Granovetter, M. (1992a). Economic institutions as social constructions: A framework for analysis. Acta Sociologica, 35,3-11.

Granovetter, M. (1992b). Problems of explanation in economic sociology. In N. Nohria \& R. G. Eccles (Eds.), Networks and organizations: Structure, form, and action (pp. 25-56). Boston, MA: Harvard Business School Press.

Granovetter, M. (2005). The impact of social structure on economic outcomes. Journal of Economic Perspectives, 19(1), 33-50.

Hartman, C., \& Squires, G. D. (Eds.). (2006). There is no such thing as a natural disaster: Race, class, and Hurricane Katrina. New York: Routledge.

Hartmann, K. (1999). Differences in dealing with disaster: Research on the flood of the River Oder in the summer of 
1997. Paper presented at the 4th European Conference of Sociology, August 18-21, 1999, Vrije Universitet, Amsterdam. Retrieved July 13, 2007 from http://www.erc.gr/English/d\&scrn/klaushartmann.htm

Hebert, S., Welch, D., St. George, A., Berrien, J., Schwartz, A., Mueller, E., \& Parkes, S. R. (2002). AECF Jobs Initiative: Evaluation of the capacity building phase, April 1997-2000. Boston, MA: Abt Associates and New York: The New School University.

Hilhorst, D. (2003). Unlocking disaster paradigms: An actor-oriented focus on disaster response. Paper presented at the $6^{\text {th }}$ European Conference of Sociology, September 23-26, 2003, Murcia, Spain.

Holcombe, E. (2007). Understanding community-based disaster response: Houston's religious congregations and Hurricane Katrina's relief efforts. In D. L. Brunsma, D. Overfelt, \& J. S. Picou (Eds.), The sociology of Katrina: Perspectives on a modern catastrophe (pp. 107-119). Lanham, MD: Rowman \& Littlefield.

Hurlbert, J. S., Beggs, J. J., \& Haines, V. A. (2006). Bridges over troubled waters: What are the optimal networks for Katrina's victims? Paper prepared in Sept./Oct. 2005 for the Social Science Research Council, published June 11, 2006. Retrieved July 13, 2007 from http://understandingkatrina.ssrc.org/Hurlbert Beggs Haines/printable.html

Hurlbert, J. S., Haines, V. A., \& Beggs, J. J. (2000). Core networks and tie activation: What kinds of routine networks allocate resources in nonroutine situations? American Sociological Review, 65, 598-618.

Ibata-Arens, K., Dierkes, J., \& Zorn, D. (2006). Guest editors' introduction: Theoretical introduction to the special 
issue on the embedded enterprise. Enterprise \& Society, 7(1), 1-18.

Iversen, R. R., \& Armstrong, A. L. (2006). Jobs aren't enough: Toward a new economic mobility for low-income families. Philadelphia: Temple University Press.

Jagd, S. (2007). Economics of convention and new economic sociology. Current Sociology, 55(1), 75-91.

Johnson, T. (2008, May 17). Quake puts focus on poorly built schools. The Philadelphia Inquirer, p. A2.

Kamenetz, A. (2005, December 1). Black out. The Village Voice. Retrieved July 29, 2007 from

http://www.villagevoice.com

Kettl, D. F. (2006). Is the worst yet to come? Annals of the American Academy of Political Science, 604, 273-287.

Kiesling, L., \& Irons, J. S. (2005). The economics of rebuilding. Wall Street Journal, October 4. Retrieved May 11, 2008 from http://online.wsj.com

Krippner, G. R., \& Alvarez, A. S. (2007). Embeddedness and the intellectual projects of economic sociology. Annual Review of Sociology, 33, 219-240.

Krippner, G., Granovetter, M., Block, F., Biggart, N., \& Beamish, T. (2004). Polanyi symposium: A conversation on embeddedness. Socio-Economic Review, 2, 109-135.

Kroll-Smith, S. (2001). Review of The Northbridge earthquake: Vulnerability and disaster, by R. Bolin with L. Stanford. Contemporary Sociology, 30(2), 175-176.

Lazer, D. (2006). Structural versus relational embeddedness: A useful concept for effective knowledge 
sharing within firms? Retrieved February 19, 2008, from www.iq.harvard.edu/blog/netgov/2006/02/structural_vs_rel ational_embed.html

Lehrer, J. (2008, April 1). In New Orleans, reinventing the idea of public housing. Online NewsHour report. Retrieved April 15, 2008 from www.pbs.org

Liu, A., \& Plyer, A. (2008). The New Orleans Index.

Washington, DC: Brookings Institution, and New Orleans:

Greater New Orleans Community Data Center.

Logan, J. R. (2006). The impact of Katrina: Race and class in storm-damaged neighborhoods. Retrieved June 20, 2008 from www.s4.brown.edu

Louisiana Department of Education. (2001). Reaching for results: 2000-2001 school report card for parents.

Retrieved September 8, 2002 from http://www.lcet.doe.la.us

Louisiana Department of Social Services. (2008). Child Care Assistance Program (CCAP). Retrieved June 23, 2008 from http://www.dss.louisiana.gov/departments/ofs/Child Care Assistance Program.html

Marcus, G. E. (1998) Ethnography through thick and thin. Princeton, NJ: Princeton University Press.

Maruyama, G., \& Ruscher, J. B. (2006). Postscript and a call for change. Analyses of Social Issues and Public Policy, 6(1), 255-261.

McEntire, D. A., Fuller, C., Johnston, C. W., \& Weber, R. (2002). A comparison of disaster paradigms: The search for a holistic policy guide. Public Administration Review, 62(3), 267-281. 
Miller, D. S., \& Rivera, J. D. (2007). Landscapes of disaster and place orientation in the aftermath of Hurricane Katrina. In D. L. Brunsma, D. Overfelt, \& J. S. Picou (Eds.), The sociology of Katrina: Perspectives on a modern catastrophe (pp. 141-154). Lanham, MD: Rowman \& Littlefield.

Montuori, A., \& Purser, R. (1996). Ecological futures: Systems theory, postmodernism, and participative learning in an age of uncertainty. In D. Boje, D. Gephart, \& T. Joseph (Eds.), Postmodernism and organization theory (pp. 181-201). Newbury Park, CA: Sage.

Moody, J., \& White, D. R. (2003). Structural cohesion and embeddedness: A hierarchical concept of social groups. American Sociological Review, 68(1), 103-127.

Muro, M., Lieu, A., Sohmer, R., Warren, D., Park, D., et al. (2005). New Orleans after the storm: Lessons from the past, a plan for the future. Washington, DC: Brookings Institution.

Napier, J. L., Mandizodza, A. N., Anderson, S. M., \& Jost, J. T. (2006). System justification in responding to the poor and displaced in the aftermath of Hurricane Katrina.

Analyses of Social Issues and Public Policy, 6(1), 57-73.

Needels, K., Corson, W., \& Nicholson, W. (2001). Left out of the boom economy. Report \#8573. Princeton, NJ:

Mathematica Policy Research.

Nelson, R. (2003, May 10). Orleans scores stagnate. The Times-Picayune, A1, 3.

Oliver-Smith, A. (1996). Anthropological research on hazards and disasters. Annual Review of Anthropology, 25, 303-328. 
Oliver-Smith, A. (2006). Disasters and forced migration in the 21st century. Retrieved June 21, 2008 from http://understandingkatrina.ssrc.org/Oliver-Smith

Ostrander, S. A. (1995). Money for change. Philadelphia: Temple University Press.

Ouroussoff, N. (2006, November 19). All fall down. New York Times, Sec. 4, pp. 1, 14.

Ouroussoff, N. (2007, December 19). High noon in New Orleans: The bulldozers are ready. New York Times, pp. B1, 6.

Padgett, D. K. (2008). Qualitative methods in social work research (2nd ed.). Thousand Oaks, CA: Sage.

Perry, R. W. (2005). Disasters, definitions and theory construction. In R. W. Perry \& E. L. Quarantelli (Eds.), What is a disaster?: New answers to old questions (pp. 311-324). Philadelphia: Xlibris.

Perry, R. W., \& Quarantelli, E. L. (2005). What is a disaster?: New answers to old questions. Philadelphia: Xlibris.

Picou, J. S., \& Marshall, B. K. (2007). Katrina as a paradigm shift: Reflections on disaster research in the twenty-first century. In D. L. Brunsma, D. Overfelt, \& J. S. Picou (Eds.), The sociology of Katrina: Perspectives on a modern catastrophe (pp. 1-20). Lanham, MD: Rowman \& Littlefield.

Plaisance, S. (2006, August 8). A jump on the school year. The Philadelphia Inquirer,p.A3. 
Plyer, A. (2007). The Katrina Index. New Orleans, LA: Greater New Orleans Community Data Center and Washington, DC: Brookings Institution.

Polanyi, K. (2001). The great transformation. Boston: Beacon. (Original work published in 1944.)

Portes, A., \& Sensenbrenner, J. (1993). Embeddedness and immigration: Notes on the social determinants of economic action. American Journal of Sociology, 98(6), 1320-1350.

Quarantelli, E. L. (2005). A social science research agenda for the disasters of the 21st century: Theoretical, methodological and empirical issues and their professional implementation. In R. W. Perry \& E. S. Quarantelli (Eds.), What is a disaster?: New answers to old questions (pp. 325-396). Philadelphia: Xlibris.

Quarantelli, E. L. (2006). Catastrophes are different from disasters: Some implications for crisis planning and managing drawn from Katrina. Retrieved July 13, 2007, from http://www.understandingkatrina.ssrc.org/Quarantelli

Revkin, A. C. (2008, May 11). The dangers of the deltas. The New York Times, Week in Review section (WK), p. 3.

Rodríguez, H., Trainor, J., \& Quarantelli, E. L. (2006). Rising to the challenges of a catastrophe: The emergent and prosocial behavior following Hurricane Katrina. Annals of the American Academy of Political Science, 604, 82-101.

Schemo, D. J. (2006, September 2). At 2-year colleges, students eager but unprepared. The New York Times. Retrieved August 4, 2007 from http://select.nytimes.com/search 
Schemo, D. J. (2007, July 10). Senate approves major overhaul of the federal student aid program. The New York Times. Retrieved August 4, 2007 from http://select.nytimes.com/search

Schweizer, T. (1997). Embeddedness of ethnographic cases: A social networks perspective. Current Anthropology, 38(5), 739-760.

Smith, N. 2006. There's no such thing as a natural disaster. Social Science Research Council. Retrieved July 13, 2007 from

http://understandingkatrina.ssrc.org/Smith/printable.html

Stahl, B. C., Lichtenstein, Y., \& Mangan, A. (2003). The limits of risk management-A social construction approach. Communications of the International Information Management Association, 3(3), 15-22.

Stallings, R. (2002). Weberian political sociology and sociological disaster studies. Sociological Forum, 17(2), 281-305.

Stallings, R. (2005). Disaster, crisis, collective stress, and mass deprivation. In R. W. Perry \& E. L. Quarantelli (Eds.), What is a disaster?: New answers to old questions (pp. 237-274). Philadelphia: Xlibris.

Swedberg, R. (1997). New economic sociology: What has been accomplished, what is ahead? Acta Sociologica, 40, 161-182.

Swedberg, R. (2003). Principles of economic sociology. Princeton, NJ: Princeton University Press.

Taylor, J. G. (1984). Louisiana: A history. New York: W.W. Norton. 
Tierney, K. (2006). The red pill. Social Science Research Council, June 11. Retrieved May 17, 2008 from http://understandingkatrina.ssrc.org/Tierney/printable.html

Tierney, K. (2007). From the margins to the mainstream? Disaster research at the crossroads. Annual Review of Sociology, 33, 503-525.

Tierney, K., Bevc, C., \& Kuligowski, E. (2006). Metaphors matter: Disaster myths, media frames, and their consequences in Hurricane Katrina. Annals of the American Academy of Political and Social Science, 604, 57-81.

Trigilia, C. (2007). Unbalanced growth: Why is economic sociology stronger in theory than in policies? Current Sociology, 55(1), 59-74.

U.S. Department of Health and Human Services. (2001). Fiscal year 2001: Characteristics and financial circumstances of TANF recipients. Washington, DC: Author, Administration for Children \& Families. Retrieved August 18, 2004 from www.acf.dhhs.gov/programs/ofa/character/FY2001/charace ristics.htm

United States Risk Management, L.L.C. (2007). "Environmental justice study: " $X$ " Housing development, New Orleans, Louisiana.” USRM Project No. 15060166. New Orleans, LA: Author.

Venton, P., \& Hansford, B. (2006). Reducing risk of disaster in our communities. Teddington, UK: Tearfund.

Weber, M. (1978). Economy and society, Volumes I and II. In G. Roth \& C. Wittich (Eds.). Berkeley, CA: University of California Press. (Original work published 1922). 
Willis, P. (2000). The ethnographic imagination. Cambridge, UK: Polity.

Wisner, B. (2001). 'Vulnerability' in disaster theory and practice: From soup to taxonomy, then to analysis and finally tool. Paper presented at the International Work-Conference, Disaster Studies of Wageningen University and Research Centre, 29/30 June, 2001.

Zelizer, V. (2002). Intimate transactions. In M. F. Guillen, R. Collins, P. England, \& M. Meyer (Eds.), The new economic sociology: Developments in an emerging field (pp. 274-300). New York: Russell Sage Foundation.

Zukin, S., \& DiMaggio, P. (1990). Introduction. In S. Zukin \& P. DiMaggio (Eds.), Structures of capital (pp. 1-36). Cambridge, UK: Cambridge University Press.

ROBERTA REHNER IVERSEN, PhD, is an associate professor of social work in the School of Social Policy \& Practice at the University of Pennsylvania. Her ethnographic research focuses on economic mobility and low-income inner-city families. The analysis in ASAP is an extension of the grant-funded ethnography that resulted in Jobs Aren't Enough: Toward a New Mobility for LowIncome Families (coauthor Annie Laurie Armstrong), published in 2006 by Temple University Press. That fiveyear, five-city project followed 25 families and over 1,000 auxiliaries and resulted in policy changes and program improvements in both welfare and workforce development arenas.

ANNIE LAURIE ARMSTRONG has been the owner of Business Government Community Connections, a national research and evaluation firm which focuses on education, 
economic security, and social justice issues, since 1981. She has a Master's degree in Public Administration from the University of Washington. She is an ethnographer and coauthor of Jobs Aren't Enough, a book that portrays the economic mobility experiences of 25 families from five cities. She is also an activist and proponent for whole family services, and has worked to successfully craft policy and funding strategies to support integrated education, employment, and human service efforts.

This research was generously supported by independent grants to the first author from the Annie E. Casey Foundation, although the contents of this article do not necessarily reflect the opinions of the Foundation. The authors are grateful to the New Orleans families for their participation, and to the local ethnographic team and the intermediary administrator for their penetrating insights into present-day New Orleans. We also appreciate the extremely thoughtful comments from the anonymous reviewers and from Professor Laurie O’Brian, all of whom significantly enriched this article. 